\title{
WEB-GIS KESESUAIAN LAHAN UNTUK PENGEMBANGAN HUTAN KOTA MENGGUNAKAN METODE MULTI-CRITERIA DECISION MAKING
}

\author{
${ }^{1)}$ Maurits Walalayo, ${ }^{2)}$ Anik Vega Vitianingsih* ${ }^{3)}$ Anastasia Lidya Maukar, ${ }^{4)}$ Erri Wahyu \\ Puspitarini, ${ }^{5}$ Fitri Marissa \\ ${ }^{1,2)}$ Teknik Informatika, Universitas Dr. Soetomo, Surabaya, Indonesia \\ ${ }^{3)}$ Industrial Engineering Department, President University, Bekasi, Indonesia \\ ${ }^{4)}$ Teknik Informatika, Universitas Widyagama, Malang, Indonesia \\ ${ }^{5)}$ Teknik Informatika, STMIK Yadika Bangil, Pasuruan, Indonesia \\ E-mail : ')walalayooces@gmail.com, ${ }^{2}$ vega@unitomo.ac.id*, ${ }^{3)}$ almaukar@gmail.com, ${ }^{4)}$ www.erri@stmik- \\ yadika.ac.id, ${ }^{5}$ fitrimarisa@widyagama.ac.id
}

\begin{abstract}
ABSTRAK
Hutan menjadi hamparan lahan yang bertumbuhan pohon-pohon yang kompak dan rapat di dalam wilayah perkotaan baik pada tanah negara maupun tanah hak. Hutan kota pada daerah perkotaan ditentukan oleh pejabat yang berwenang. Fungsi hutan kota untuk memperbaiki dan menjaga iklim mikro dan nilai estetika, meresapkan air, dan mendukung pelestarian keanekaragaman hayati Indonesia. Perlu adanya penanganan penting untuk mengatasi masalah tersebut, salah satunya adalah dengan mengembangkan RTH jenis Hutan Kota di Kabupaten Sidoarjo. Dinas Lingkungan Hidup dan Kebersihan (DLHK) Kabupaten Sidoarjo adalah salah satu lembaga yang mengantur tentang pembangunan hutan kota. Namun pihak DLHK masih belum tau daerah mana sajakah di Kabupaten Sidoarjo yang lahannya bisa untuk dibuat hutan kota. Tujuan dari penelitian ini adalah untuk memberikan informasi mengenai pengembangan lahan yang cocok untuk dijadikan sebagai hutan Kota tipe kawasan permukiman berbasis Web-GIS di Kabupaten Sidoarjo. Metode yang digunakan untuk pemodelan data spasial menggunakan Multi-Criteria Decision Making (MCDM) diantaranya Analitychal Hierarchy Process (AHP) dan metode Weighted Sum Model (WSM). Parameter berdasarkan jumlah penduduk, ketinggian wilayah, banyak perusahaan, dan luas lahan standar untuk mengetahui kesesuaian lahan untuk pengembangan hutan kota pada tiap kecamatan dengan studi kasus di Kabupaten Sidoarjo. Klasifikasi hutan kota pada hasil pemodelan data spasial meliputi lahan dengan kategori tidak cocok, cocok, dan sangat cocok. Hasil uji perbandingan kedua metode MCDM menggunakan koefisien kappa Cohen $(\kappa)$ menghasilkan rata-rata nilai $\kappa=0.07$ untuk hutan kota tipe kawasan permukiman. Kesimpulan dari pemodelan data spasial untuk menggunakan metode AHP dan WSM pada hutan kota tipe kawasan permukiman memiliki hasil yang berbeda untuk digunakan dalam perhitungan kesesuaian lahan pada pengembangan hutan kota.
\end{abstract}

Kata Kunci: Web-GIS, SIG, Kesesuaian Lahan, Pengembangan Hutan Kota, Ruang Terbuka Hijau, MCDM, WSM, AHP, Cohen's Kappa.

\begin{abstract}
Forests are expanses of land that grow compact and dense trees in urban areas, both on state land and private land. Urban forests in urban areas are determined by the competent authority. The function of urban forests is to improve and maintain the microclimate and aesthetic value, absorb water, and support the preservation of Indonesia's biodiversity. The Department of Environment and Hygiene (DLHK) of Sidoarjo Regency is one of the institutions that regulates urban forest development. However, the DLHK still doesn't know which areas in Sidoarjo Regency can make urban forests. The purpose of this study is to provide information on the development of land suitable for use as urban forest, a type of residential area based on Web-GIS in Sidoarjo Regency. The methods used for modeling spatial data using Multi-Criteria Decision Making (MCDM) include the Analytical Hierarchy Process (AHP) and the Weighted Sum Model (WSM) method. Parameters based on population, area height, number of companies, and standard land area to determine land suitability for urban forest development in each sub-district with a case study in Sidoarjo Regency. The classification of urban forests on the results of spatial data modeling includes land with unsuitable, suitable, and very suitable categories. The results of the comparison test of the two MCDM methods using Cohen's kappa coefficient $(\kappa)$ resulted in an average value of = 0.07 for urban forests with residential areas. Conclusions from spatial data modeling to use AHP and WSM methods in urban forest residential area types have different results to be used in the calculation of land suitability in urban forest development.
\end{abstract}

Keyword: Web-GIS, GIS, Land Suitability, Urban Forest Development, Green Open Space, MCDM, WSM, AHP, Cohen's Kappa. 


\section{PENDAHULUAN.}

Berdasarkan Peraturan Pemerintah Nomor 63 Tahun 2002 Tentang Hutan Kota, Hutan kota adalah suatu hamparan lahan yang bertumbuhan pohon-pohon yang kompak dan rapat di dalam wilayah perkotaan baik pada tanah negara maupun tanah hak, yang ditetapkan sebagai hutan kota oleh pejabat yang berwenang [1]. Fungsi hutan kota adalah untuk memperbaiki dan menjaga iklim mikro dan nilai estetika, meresapkan air, dan mendukung pelestarian keanekaragaman hayati Indonesia [2]. Hutan kota dapat juga dimanfaatkan untuk berbagai aktivitas sosial masyarakat (secara terbatas, meliputi aktivitas pasif seperti duduk dan beristirahat dan atau membaca, atau aktivitas yang aktif seperti jogging, senam atau olahraga ringan lainnya), wisata alam, rekreasi, penghasil produk hasil hutan, oksigen, ekonomi (buah-buahan, daun, sayur), wahana pendidikan dan penelitian [3]. Workshop Hutan Kota Fakultas Kehutanan, merumuskan bahwa hutan kota tidak harus kompak dan rapat tetapi dapat berbentuk dari seluruh tipe lahan diperkotaan yang kehadiran kumpulan pepohonan dapat menciptakan iklim mikro sehingga tipe dan bentuknya bervariasi [4]. Oleh sebab itu, hutan kota sangat diperlukan untuk dapat menciptakan keseimbangan dan keserasian lingkungan fisik sebuah kota.

Kabupaten Sidoarjo merupakan sebuah Kabupaten di Provinsi Jawa Timur, Indonesia yang memiliki jumlah penduduk terbanyak ke tiga di Provinsi Jawa Timur. Menurut data yang ada pada Provinsi Jawa Timur dalam angka 2020 mengenai penduduk dan ketenagakerjaan yang ada di Jawa Timur, Kabupaten Sidoarjo berada pada urutan ke tiga sebagai wilayah yang mempunyai jumlah penduduk yang cukup banyak. Ada 2.249 jiwa yang ada di Kabupaten Sidoarjo [5]. Seiring berjalannya waktu, jumlah penduduk di Kabupaten Sidoarjo dapat saja bertambah dan dapat juga memberi dampak bagi lingkungan sekitar seperti pencemaran lingkungan oleh limbah sampah rumah tangga dan berkurangnya ketersediaan ruang dan lahan pertanian. Kabupaten Sidoarjo juga terkenal sebagai kota industri, terbukti dari data yang ada pada Provinsi Jawa Timur dalam angka 2020 mengenai jumlah perusahaan pada industri besar dan sedang menurut Kabupaten/Kota di Provinsi Jawa Timur, Kabupaten Sidoarjo berada pada urutan pertama sebagai wilayah yang mempunyai jumlah perusahaan terbanyak ditingkat Jawa Timur. Ada 1.094 Perusahaan industri yang ada di Kabupaten Sidoarjo [5]. Hal ini pastinya dapat berdampak pada kondisi lingkungan di Kabupaten Sidoarjo, salah satunya pencemaran udara yang disebabkan oleh asap dari pabrik atau perusahaan yang ada di Kabupaten Sidoarjo.

Perlu adanya penanganan penting untuk mengatasi masalah diatas, seperti pengembangan lokasi Ruang Terbuka Hijau (RTH) di wilayah Kabupaten Sidoarjo demi mengurangi dampak tersebut. Namun dalam pengembangan lokasi RTH sendiri, Kabupaten Sidoarjo hanya mampu memenuhi kuota 21,6\% [6]. Ketersediaan RTH Kabupaten Sidoarjo secara keseluruhan masih dianggap kurang karena belum memenuhi kuota minimal 30\% dari luas wilayah seperti yang diamanatkan pada peraturan penataan ruang [6].

Dari beberapa permasalahan mengenai jumlah penduduk, jumlah industri pada perusahaan besar dan sedang, serta kurangnya RTH di Kabupaten Sidoarjo, maka penting untuk mengembangkan RTH di Kabupaten Sidoarjo, salah satunya adalah mengembangkan RTH jenis Hutan Kota.

Dinas Lingkungan Hidup dan Kebersihan (DLHK) Kabupaten Sidoarjo adalah salah satu lembaga yang mengantur tentang pembangunan hutan kota. Namun 
berdasarkan survey yang dilakukan penulis pada hari Rabu 25 November 2020, Jam 09.00 WIB di DLHK Kabupaten Sidoarjo, pihak DLHK masih belum tau daerah mana sajakah di Kabupaten Sidoarjo yang lahannya bisa untuk dibuat hutan kota. Dikarenakan pihak DLHK tidak menggunakan media seperti website untuk mendapatkan informasi geografis mengenai hutan kota di wilayah Kabupaten Sidoarjo. Untuk itu dari beberapa masalah diatas inilah yang menjadi alasan penulis untuk melakukan penelitian di Dinas Lingkungan Hidup dan Kebersihan Kabupaten Sidoarjo.

Pada penelitian sebelumnya, Sari Narulita (2016) menggunakan metode AHP untuk menentukan prioritas lokasi yang dapat dikategorikan menjadi hutan kota dengan menggunakan parameter ketinggian, kemiringan, tutupan lahan, iklim, kepadatan penduduk, dan jarak jalan protokol memberikan hasil kabupaten harus dikembangkan menjadi hutan kota di Bandung itu Mandalajati, Cibiru, dan Ujung Berung [7]. Penelitian Gumilar Adam (2017) menggunakan metode scoring dan AHP untuk menentukan jenis hutan kota yang tepat dan untuk mengidentifikasi bentuk hutan kota di Kota Tangerang Selatan dengan menggunakan parameter suhu udara, kemiringan lahan, dan jenis tanah memberikan hasil lokasi dan prioritas untuk pengembangan setiap jenis hutan kota adalah sebagai berikut: (a) kawasan perumahan tipe hutan kota dengan luas area 355,57 ha didistribusikan di Kecamatan Pamulang, CiputatTimur, Serpong, Serpong Utara, dan Setu; (b) Jenis hutan kota industri dengan ukuran area 10,81 ha didistribusikan di Kecamatan Ciputat Timur dan Serpong Utara; (c) tipe hutan kota rekreasi dengan ukuran area 25,45 ha didistribusikan di kecamatan Serpong dan Serpong Utara [8]. Kemudian, penelitian Yu Zheng (2019) menggunakan metode AHP dan pemodelan sensitifitas ekologis untuk membuat aplikasi GIS dalam perencanaan taman hutan kota menggunakan parameter ketinggian, kemiringan, tipe hutan, dan jarak ke sungai memberikan hasil dukungan keputusan ilmiah untuk penggunaan lokasi studi dan juga menunjukan keberhasilan metodologi yang diusulkan untuk perencanaan berkelanjutan taman hutan kota [9]. Oleh karena itu penelitian yang telah dilakukan belum menggunakan parameter dan metode yang akan diusulkan di pembahasan makalah ini, dengan parameter jumlah penduduk, banyak perusahaan, ketinggian wilayah, luas lahan standar dengan analisa menggunakan metode AHP dan WSM untuk kesesuaian lahan pengembangan hutan kota.

Ada beberapa perbedaan dari penelitian ini dengan penelitian sebelumnya Sari Narulita (2016), Gumilar Adam (2017), dan $\mathrm{Yu}$ Zheng (2019). Dimana perbedaan pertama adalah terdapat pada parameter yang digunakan. Sari Narulita (2016) menggunakan parameter ketinggian, kemiringan, tutupan lahan, iklim, kepadatan penduduk, dan jarak jalan protokol. Gumilar Adam (2017) menggunakan parameter suhu udara, kemiringan lahan, dan jenis tanah. Yu Zheng (2019) menggunakan parameter ketinggian, kemiringan, tipe hutan, dan jarak ke sungai. Sedangkan pada penilitian ini menggunakan parameter yang berdasar pada Peraturan Menteri Kehutanan Republik Indonesia Nomor:P.71/Menhut-II/2009 pasal 8 ayat 1 Tentang Pedoman Penyelenggaraan Hutan Kota yaitu jumlah penduduk, ketingian wilayah, banyak perusahaan, dan luas lahan standar.

Perbedaan kedua adalah pada penggunaan metode yang digunakan. Sari Narulita (2016) hanya menggunakan 1 metode yaitu metode AHP untuk menentukan prioritas lokasi yang dapat dikategorikan menjadi hutan kota. Gumilar Adam (2017) menggunakan 2 metode, yaitu metode scoring dan metode AHP 
untuk menentukan jenis hutan kota yang tepat dan untuk mengidentifikasi bentuk hutan kota di Kota Tangerang Selatan, dan Yu Zheng (2019) hanya menggunaakan 1 metode yaitu metode AHP dan pemodelan sensitifitas ekologis untuk membuat aplikasi GIS dalam perencanaan taman hutan kota. Sedangkan pada penilitian ini menggunakan 2 metode, yaitu metode AHP dan metode WSM untuk dapat mengetahui daerah mana di Kabupaten Sidoarjo yang lahanya cocok untuk dijadikan hutan kota tipe kawasan permukiman.

Sistem Informasi Geografis merupakan sistem yang dirancang untuk bekerja dengan data yang tereferensi secara spasial [10]. SIG merupakan gabungan dari tiga unsur pokok yaitu sistem, informasi, dan geografis, yang mana lebih menekankan pada unsur informasi geografis. Makna informasi geografis adalah penyajian informasi mengenai posisi suatu obyek di permukaan bumi dan atributnya [10].

Tujuan dari penelitian ini adalah untuk membuat Web-GIS untuk dapat mengetahui daerah mana di Kabupaten Sidoarjo yang lahanya cocok untuk dijadikan hutan kota tipe kawasan permukiman dengan klasifikasi hutan kota tidak cocok, cocok, dan Sangat cocok berdasarkan parameter jumlah penduduk, ketingian wilayah, banyak perusahaan, dan luas lahan standar yang berdasar pada Peraturan Menteri Kehutanan Republik Indonesia Nomor:P.71/Menhut-II/2009 pasal 8 ayat 1 Tentang Pedoman Penyelenggaraan Hutan Kota [2]. Metode yang digunakan dalam penelitian ini menggunakan metode Analytical Hierarchy Process (AHP) dan Metode Weighted Sum Model (WSM) pada MultiCriteria Decision Making (MCDM).

\section{Spasial Data Set}

Spasial data meliputi jumlah penduduk, ketinggian wilayah, banyak perusahaan, dan luas lahan standar yang kemudian dihitung menggunakan metode AHP dan metode WSM. Perolehan data-data yang diperlukan diperoleh dari Badan Perencana Pembangunan Daerah (BPPD), Badan Pusat Statistik (BPS), Dinas Kependudukan dan Pencatatan Sipil, Dinas Lingkungan Hidup dan Kebersihan (DLHK) Kabupaten Sidoarjo.

Table 1. Perolehan data dan data atribut

\begin{tabular}{ll}
\hline \multicolumn{1}{c}{ Data Atribut } & \multicolumn{1}{c}{ Sumber } \\
\hline $\begin{array}{l}\text { Peta Kabupaten Sidoarjo dan Land use } \\
\text { Kabupaten Sidoarjo }\end{array}$ & Badan Perencana Pembangunan Daerah \\
\hline $\begin{array}{l}\text { Jumlah Penduduk di tiap kecamatan } \\
\text { Kabupaten Sidoarjo }\end{array}$ & $\begin{array}{l}\text { Dinas Kependudukan dan Pencatatan Sipil } \\
\text { Kabupaten Sidoarjo (Buku Kabupaten Sidoarjo } \\
\text { Dalam angka 2020) }\end{array}$ \\
\hline Banyak Perusahaan/Industri di tiap & Badan Pusat Statistik Kabupaten Sidoarjo \\
kecamatan Kabupaten Sidoarjo & (Buku Kabupaten Sidoarjo Dalam angka 2020) \\
\hline Ukuran Ketinggian Wilayah di tiap & Badan Pusat Statistik Kabupaten Sidoarjo \\
kecamatan Kabupaten Sidoarjo & (Buku Kabupaten Sidoarjo Dalam angka 2020) \\
\hline $\begin{array}{l}\text { Luas Lahan Standar/lahan kosong di tiap } \\
\text { kecamatan Kabupaten Sidoarjo }\end{array}$ & $\begin{array}{l}\text { Dinas Lingkungan Hidup dan Kebersihan } \\
\text { Kabupaten Sidoarjo (Buku Kabupaten Sidoarjo }\end{array}$ \\
\hline
\end{tabular}

\section{METODE}

Tahapan proses dalam pemodelan spasial Web-GIS kesesuaian lahan untuk pengembangan hutan kota di Kabupaten Sidoarjo ditunjukan pada Gambar 1. 


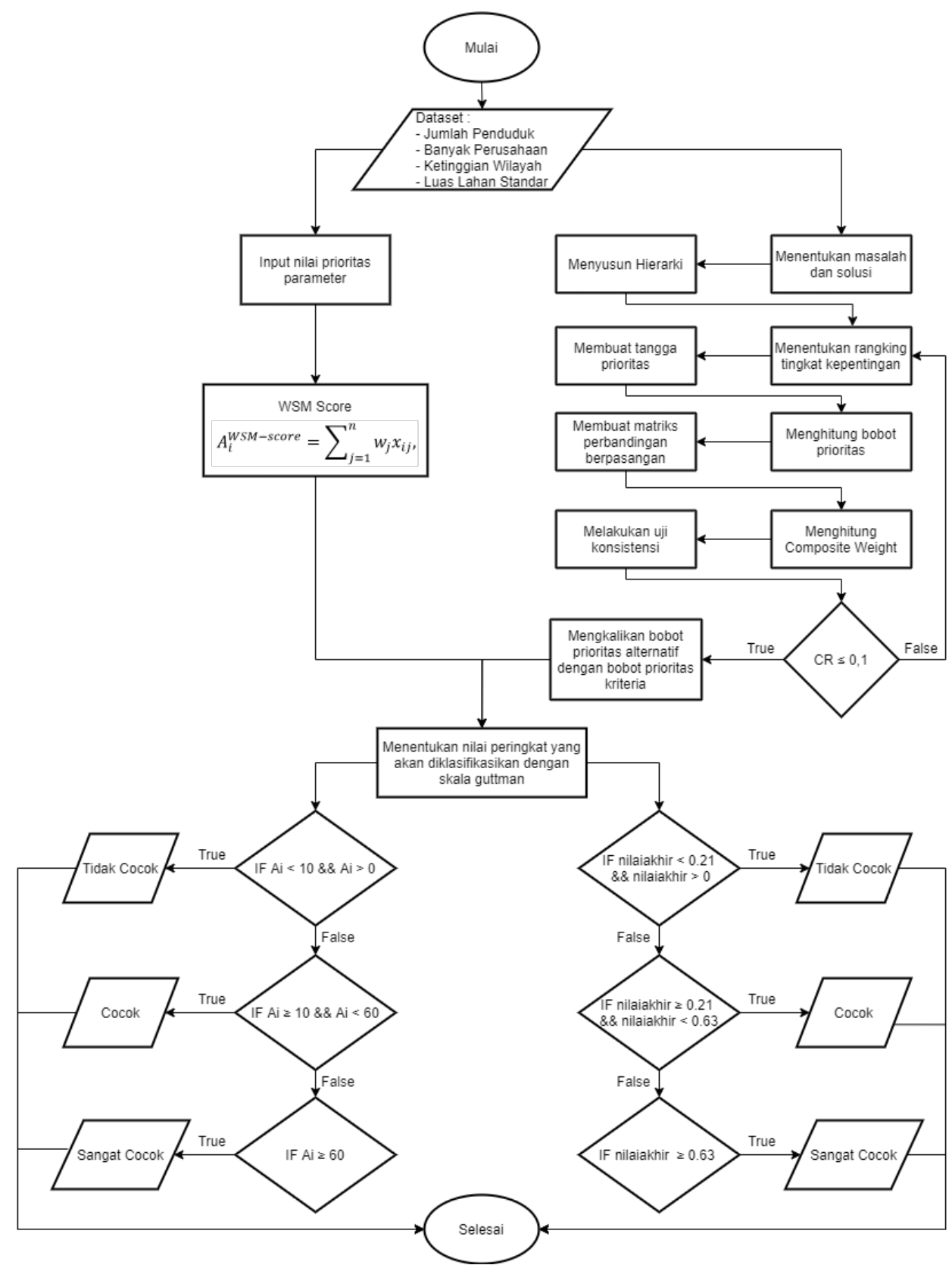

Gambar 1. Flowchart Metode WSM dan Metode AHP

Tahap ini memberikan gambaran sistem bekerja. Mulai dari memasukkan kebutuhan data, kemudian dilakukan proses pemodelan spasial data dengan metode yang cocok dengan perilaku data yang diperoleh dari pencatatan proses, bagian akhir adalah menampilkan hasil pemodelan data spasial sesuai dengan fungsi dan tujuan yang ingin dicapai dalam SIG [11].

Langkah pertama, pendefinisian data spasial dan data atribut. Dataset tersebut mencakup peta Kabupten Sidoarjo, jumlah penduduk tiap kecamatan, banyak perusahaan tiap kecamatan, ukuran ketinggian wilayah tiap kecamatan, dan luas lahan standar atau jumlah lahan kosong yang ada di tiap kecamatan yang didapat dari Tabel 1 . Kemudian diklasifikasikan menggunakan skala Guttman dengan 3 klasifikasi yaitu Tidak cocok, Cocok, dan Sangat cocok. Hasil akhir akan dilakukan perbandingan hasil perhitungan metode AHP dan metode WSM, yang kemudian dapat diketahui wilayah mana di Kabupaten Sidoarjo yang lahannya tidak cocok, cocok, dan sangat cocok untuk hutan 
kota.

\section{A. Analytical Hierarchy Process (AHP)}

Metode pengambilan keputusan dengan Analytical Hierarchy Process (AHP) pertama kali dikembangkan pada tahun 1980, oleh Thomas L [12]. Metode AHP merupakan metode yang ada dalam system pendukung keputusan yang memiliki keunikan dibandingkan dengan metode yang lainnya
[13]. Hal ini dikarenakan dalam pembobotan kriteria, bobot dari setiap kriteria bukan ditentukan di awal tetapi ditentukan menggunakan rumus dari metode ini berdasarkan skala prioritas (tingkat kepentingan). Tingkat kepentingan dari metode AHP dapat dilihat pada Tabel 2.

Table 2. Nilai Kepentingan AHP

\begin{tabular}{ccl}
\hline No & Nilai Kepentingan & \multicolumn{1}{c}{ Keterangan } \\
\hline 1. & 1 & Sama penting \\
\hline 2. & 3 & $\begin{array}{l}\text { Cukup penting (1 level lebih penting dibandingkan kriteria } \\
\text { lainnya }\end{array}$ \\
\hline 3. & 5 & $\begin{array}{l}\text { Lebih penting (2 level lebih penting dibandingkan kriteria } \\
\text { lainnya }\end{array}$ \\
\hline 5. & 7 & $\begin{array}{l}\text { Sangat lebih penting (3 level lebih penting dibandingkan } \\
\text { kriteria lainnya) }\end{array}$ \\
\hline 6. & $\begin{array}{l}\text { Mutlak lebih penting (4 level lebih penting dibandingkan } \\
\text { kriteria lainnya) }\end{array}$ \\
\hline 5 & $2,4,6,8$ & $\begin{array}{l}\text { Nilai-nilai antar dua nilai pertimbangan-pertimbangan } \\
\text { berdekatan. Nilai ini diberikan bila ada dua kompromi } \\
\text { diantara dua pilihan }\end{array}$ \\
\hline
\end{tabular}

Sumber : M. K. Dicky Nofriansyah, S.Kom. and M. S. Prof. Dr. Sarjon Defit, S.Kom., 2019 [13]

Metode AHP memiliki nilai Consistency Ratio (CR) seperti terlihat pada Tabel 3, dimana variabel Jumlah $n$ Kriteria merupakan banyaknya kriteria atau parameter yang digunakan. Jika parameter yang digunakan misalkan sebanyak 3, maka nilai dari $I R$ nya adalah 0.58 . Variabel $I R$ merupakan nilai dari Jumlah $n$ Kriteria yang digunakan [13]. Nilai CR dalam AHP digunakan untuk mengukur konsistensi dari hasil perhitungan. Jika nilai CR dari hasil perhitungan $\leq 0,1$ maka hasil perhitungan bisa dinyatakan konsisten, dan jika hasilnya $>0,1$ maka hasil perhitungan dinyatakan tidak konsisten dan harus dilakukan perhitungan ulang. Nilai CR metode AHP dapat dilihat pada Tabel 3.
Table 3. Nilai Consistency Ratio metode AHP

\begin{tabular}{cc}
\hline Jumlah $\boldsymbol{n}$ Kriteria & $\boldsymbol{I R}_{\boldsymbol{n}}$ \\
\hline 2 & 0 \\
\hline 3 & 0.58 \\
\hline 4 & 0.90 \\
\hline 5 & 1.12 \\
\hline 6 & 1.24 \\
\hline 7 & 1.32 \\
\hline 8 & 1.41 \\
\hline 9 & 1.45 \\
\hline 10 & 1.49 \\
\hline
\end{tabular}

Algoritma penyelesaian dari metode AHP adalah sebagai berikut [13]:

1. Menentukan masalah dan solusi diinginkan.

2. Membuat struktur yang terdiri dari tujuan 
atau goal, kriteria, dan alternatif.

3. Mendefinisikan kriteria-kriteria yang akan dijadikan sebagai tolak ukur penyelesaian masalah dan menetukan nilai kepentingan dari setiap kriteria dan alternatif kriteria berdasarkan Tabel 2.

4. Membuat matriks perbandingan berpasangan kriteria dan alternatif kriteria berdasarkan nilai kepentingan Tabel 2 .

5. Menghitung bobot prioritas kriteria dan alternatif kriteria dengan tahapan sebagai berikut:

- Jumlahkan nilai pada satu kolom dan lakukan pada setiap kolom pada Persamaan (1).

$\sum_{i=1}^{n} a_{i j}, \quad j=1,2,3 \ldots n$

dimana variabel $a_{i j}$ merupakan nilai pada suatu matriks pada baris ke-i dan kolom ke-j.

- Membagi nilai setiap kolom dengan hasil jumlah nilai kolom (Persamaan 1), sehingga nilai jumlah kolom yang baru sama dengan satu pada Persamaan (2).

$\sum_{1}^{n} \frac{a_{i j}}{\sum_{i=1}^{n} a_{i j}}=1, j=1,2,3 \ldots n$

dimana variable $a_{i j}$ merupakan nilai pada baris ke-i dan kolom ke-j.

- Menjumlahkan nilai tiap baris dari hasil pembagian tiap kolom matriks (Persamaan 2) pada Persamaan (3).

$\sum_{j=1}^{n} a_{i j}, \quad i=1,2,3 \ldots n$

dimana variable $a_{i j}$ merupakan baris ke-i dan kolom ke-j.

- Membagi hasil jumlah tiap baris berdasarkan Persamaan (3) dengan banyaknya kriteria untuk mendapatkan bobot prioritas kriteria pada Persamaan (4)

$W_{i}=\frac{1}{n} \sum_{j=1}^{n} a_{i j}, j=1,2,3 \ldots n$

dimana $W_{i}$ merupakan bobot prioritas ke-i, variabel $n$ merupakan jumlah kriteria, variabel $a_{i j}$ merupakan baris ke-i dan kolom ke-j.

6. Menghitung Composite Weight $(\mathrm{CW})$ atau prioritas global. CW didapatkan dengan mengkalikan matriks nilai kepentingan awal dengan bobot prioritas kriteria pada Persamaan (5)

$$
\begin{aligned}
\sum_{j}^{n}\left(A_{1 j} \cdot W_{j}\right)= & \left(a_{i 1} \cdot w_{1}\right)+\left(a_{i 2} \cdot w_{2}\right)+ \\
& \left(a_{i 3} \cdot w_{3}\right)
\end{aligned}
$$

dimana variabel $a_{i j}$ merupakan baris ke-i dan kolom ke-j, variabel $W_{j}$ merupakan bobot prioritas ke-j.

7. Melakukan uji konsistensi dengan tahapan:

- Membagi hasil jumlah tiap baris matriks Composite Weight (Persamaan 5) dengan bobot prioritas yang bersesuaian untuk mendapatkan nilai lamda pada Persamaan (6)

$\lambda_{i}=\frac{\sum_{j=1}^{n}\left(x_{i j} \cdot w_{j}\right)}{w_{i}}, i=1,2,3, \ldots, n$

Dimana $\lambda_{i}$ merupakan eigen value pada kriteria ke-i, variabel $W_{i}$ merupakan bobot prioritas kriteria ke-i, variabel $W_{j}$ bobot prioritas kriteria ke-j, variabel $x_{i j}$ merupakan nilai pada matriks perbandingan..

- Menghitung nilai lamda maksimal ( $\left.\lambda_{\text {maks }}\right)$ pada persamaan (7).

$\lambda_{\text {maks }}=\frac{\lambda_{1}+\lambda_{2}+\cdots+\lambda_{n}}{n}$

dimana $\lambda_{\text {maks }}$ merupakan rata-rata eigen value, variabel $n$ merupakan jumlah kriteria.

- Hitung Consistency Index (CI) pada Persamaan (8)

$C I=\frac{\lambda_{\text {maks }}-n}{n-1}$

dimana $C I$ merupakan Consistency Index, variabel $\lambda_{\text {maks }}$ merupakan rata-rata eigen value, variabel $n$ merupakan jumlah kriteria.

- Hitung Consistency Ratio (CR) pada Persamaan (9)

$C R=\frac{C I}{I R}$

Dimana $C R$ merupakan Consistency Ratio, variabel $C I$ merupakan Consistency Index, variabel $I R$ merupakan Indeks Random. Jika nilai $C R$ dari hasil perhitungan $\leq 0,1$ maka hasil perhitungan bisa dinyatakan konsisten, 
dan jika hasilnya $>0,1$ maka hasil perhitungan dinyatakan tidak konsisten dan harus dilakukan perhitungan ulang. Proses perhitungan kemudian dilanjutkan dengan menghitung nilai perkalian bobot prioritas alternatif kriteria dengan bobot prioritas kriteria.

\section{B. Weighted Sum Model (WSM)}

Metode Weighted Sum Model (WSM) merupakan metode yang sangat umum, dan banyak diterapkan untuk membantu pengambilan keputusan dalam mengambil suatu keputusan [14].

Metode WSM merupakan salah satu metode yang paling sederhana dan mudah dipahami penerapannya dikarenakan dalam konsep metode ini hanya melakukan perkalian di antara Bobot Kriteria $w_{j}$ dan Nilai Alternatif $x_{i j}$ [15]. Metode ini merupakan bagian dalam metode MCDM (Multi Criteria Decision Making) dalam mengevaluasi nilai pada setiap alternatif [13].

Adapun algoritma penyelesaian dari metode ini adalah sebagai berikut [13] :

1. Mengidentifikasi nilai kriteria (bobot parameter) dan Alternatif (bobot atribut parameter) yang digunakan dalam penyelesaian masalah.

2. Menghitung Nilai WSM-Score pada Persamaan 10.

$A_{i}^{W S M-s c o r e}=\sum_{j=1}^{n} w_{j} x_{i j}$,

dimana $A_{i}^{\text {WSM-score }}$ merupakan nilai alternatif terbaik, $n$ merupakan jumlah kriteria, variabel $w_{j}$ merupakan bobot dari setiap kriteria-j, dan variabel $x_{i j}$ merupakan matriks-i pada kriteria-j.
3. Melakukan perangkingan. Proses perangkingan pada metode WSM dilakukan setelah didapatkan hasil dari setiap perhitungan pada Persamaan 10 . Hasil dari perhitungan yang nilainya paling besar, mendapatkan urutan pertama diikuti dengan nilai dan urutan selanjutnya.

\section{Skala Guttman}

Skala Guttman merupakan dasar pengukuran untuk menarik kesimpulan data kualitatif, digunakan untuk memberikan perkiraan nilai hasil klasifikasi dalam sebuah nilai intervensi yang masih ambigu karena adanya ketidakpastian [14].

Pada tipe dataset yang menggunakan skor/bobot dalam proses analisa, memberikan nilai berdasarkan faktor ketidakpastian dari kelas variable yang dideskripsikan, maka dapat dilakukan pengukuran dengan menggunakan skala Guttman [14] pada Persamaan (11).

$I=\frac{R}{K}$

dimana I merupakan hasil dari nilai interval yang diperoleh dari variabel, $R$ merupakan nilai data dan variabel $K$ merupakan jumlah alternatif klasifikasi yang dihasilkan.

Pada penelitian ini, nilai variabel $R$ diperoleh dari nilai rentang nilai antara nilai maksimum dan minimum dari hasil perhitungan metode AHP yaitu nilaiakhir dan hasil perhitungan metode WSM yaitu $A_{i}$. Variabel $K$ merupakan jumlah klasifikasi alternatif yaitu tidak cocok, cocok, dan sangat cocok yang mengacu pada Gambar 1 dan Tabel 4.

Table 4. Penilaian Skala Guttman

\begin{tabular}{l|l|l}
\hline $\begin{array}{c}\text { Jenis Hutan } \\
\text { Kota }\end{array}$ & \multicolumn{1}{|c|}{ Metode AHP } & Metode WSM \\
\hline Tipe & $\begin{array}{c}R=\text { nilai }_{\text {max }}-\text { nilai }_{\text {min }} \\
=0.84-0.22\end{array}$ & $\begin{array}{c}R=A i_{\text {max }}-A i_{\text {min }} \\
=70-40=30\end{array}$ \\
Kawasan & \multicolumn{2}{|c}{} \\
\hline
\end{tabular}




\begin{tabular}{|c|c|c|}
\hline $\begin{array}{c}\text { Jenis Hutan } \\
\text { Kota }\end{array}$ & Metode AHP & Metode WSM \\
\hline \multirow[t]{2}{*}{ Permukiman } & $\begin{array}{l}\quad=0.62 \\
K=3 \\
\begin{aligned} I=\frac{R}{K}=\frac{0.62}{3}=0.21 & \\
\text { Kriteria penilaian } & =\text { nilai }_{\text {max }}-I \\
& =0.84-0.21 \\
& =0.63\end{aligned}\end{array}$ & $\begin{array}{l}K=3 \\
\begin{aligned} & I=\frac{R}{K}=\frac{30}{3}=10 \\
& \text { Kriteria penilaian }=A i_{\text {max }}-I \\
&=70-10=60\end{aligned}\end{array}$ \\
\hline & $\begin{array}{l}\text { Penilain kriteria Tidak Cocok }= \\
\text { IF nilaiakhir }<0.21 \& \& \\
\text { nilaiakhir }>0 \\
\text { Penilain kriteria Cocok }= \\
\text { IF nilaiakhir } \geq 0.21 \& \& \\
\text { nilaiakhir }<0.63 \\
\text { Penilain kriteria Sangat Cocok }= \\
\text { IF nilaiakhir } \geq 0.63\end{array}$ & $\begin{array}{l}\text { Penilain kriteria Tidak Cocok }= \\
\text { IF } A_{i}<10 \& \& A_{i}>0 \\
\text { Penilain kriteria Cocok }= \\
\text { IF } A_{i} \geq 10 \& \& A_{i}<60 \\
\text { Penilain kriteria Sangat Cocok= } \\
\text { IF } A_{i} \geq 60\end{array}$ \\
\hline
\end{tabular}

\section{Cohen's Kappa}

Metode uji konsistensi Cohen's Kappa digunakan untuk menguji konsistensi dalam mengukur dua metode atau dua penelitian. Pengukuran dapat dilakukan berdasarkan data kualitatif [16] pada Persamaan 12.

$K=\frac{P_{o}-P_{e}}{1-P_{e}}$

Dimana variabel $K$ merupakan koefisien hasil dari pengukuran antar penelitian. Variabel $P o$ merupakan kesepakatan relatif yang diamati di antara penilai dan variabel $P e$ merupakan probalitas hipotesis kesepakatan kebetulan.

Statistik Cohen's Kappa memiliki variasi 0 hingga 1, dapat dilihat pada Tabel 5.

Table 5. Nilai Koefisien Cohen's Kappa [16]

\begin{tabular}{c|c}
\hline Nilai $\boldsymbol{\kappa}$ & Keeratan Kesepakatan \\
\hline$\leq 0.20$ & Rendah \\
$0.21-0.40$ & Lumayan \\
\hline $0.41-0.60$ & Cukup \\
\hline $0.61-0.80$ & Kuat \\
\hline $0.81-1.00$ & Sangat kuat \\
\hline
\end{tabular}

\section{HASIL}

Hasil perhitungan pada penelitian ini menggambil 1 studi kasus yaitu pada Kecamatan Buduran dengan perhitungan menggunakan metode AHP dan metode WSM berdasarkan parameter jumlah penduduk, banyak perusahaan, ketinggian wilayah, dan luas lahan standar menggunakan kriteria klasifikasi Tidak cocok, Cocok, dan Sangat cocok ditunjukan pada Gambar 2 dan Tabel 6 untuk hasil perhitungan menggunakan metode AHP dan pada Gambar 3 Tabel 6 untuk hasil perhitungan menggunakan metode WSM.

Gambar 2 Hasil Perhitungan Menggunakan Metode AHP 


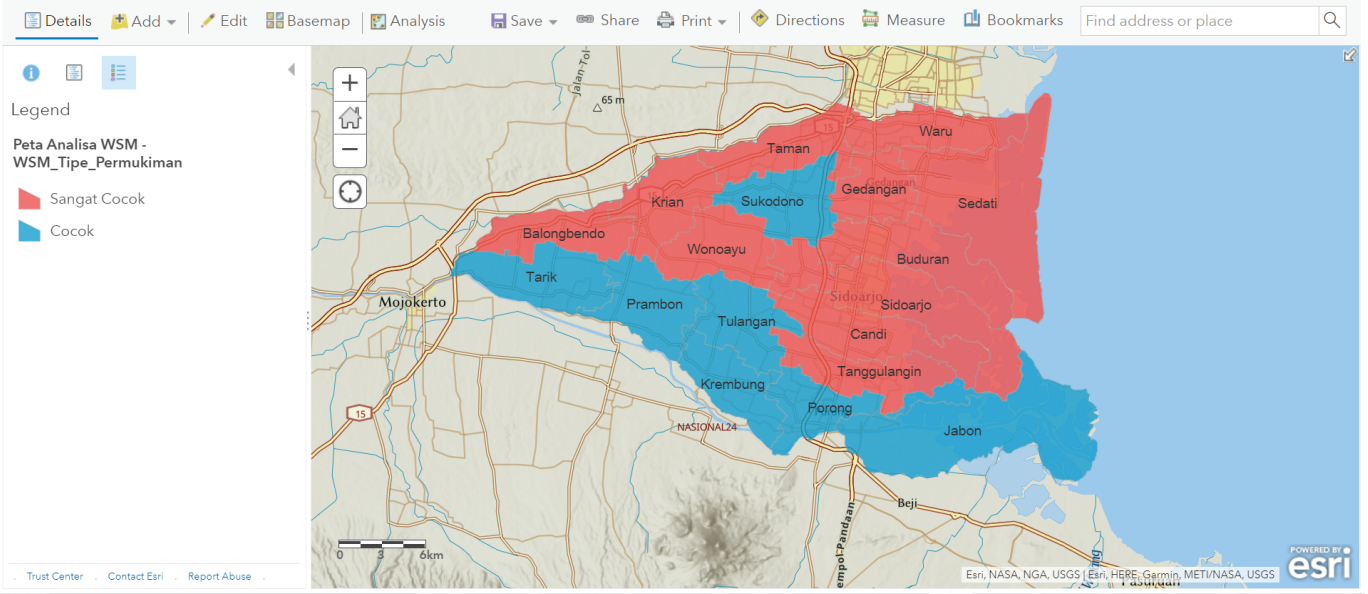

Gambar 3 Hasil Perhitungan Menggunakan Metode WSM

Table 6. Hasil Klasifikasi Hutan Kota dengan Menggunakan Metode AHP dan Metode WSM

\begin{tabular}{cccc}
\hline \multirow{2}{*}{ Hutan Kota } & \multirow{2}{*}{ Klass } & \multicolumn{2}{c}{ Hasil Masing-masing Metode Pada Tiap Kecamatan } \\
\cline { 2 - 4 } & & AHP & WSM \\
\hline Tipe & Tidak cocok & 0 & 0 \\
\cline { 2 - 4 } $\begin{array}{c}\text { kawasan } \\
\text { permukiman }\end{array}$ & Cocok & 17 & 7 \\
\cline { 2 - 4 } & Sangat cocok & 1 & 11 \\
\hline
\end{tabular}

Hasil klasifikasi hutan kota tiap masing-masing tipe pada Tabel 6 dengan kriteria tidak cocok, cocok, dan sangat cocok pada metode AHP dihitung dengan tahapan sebagai berikut :

1. Menentukan masalah dan solusi.

Masalah dalam penelitian ini adalah untuk menentukan lokasi lahan yang cocok untuk dijadikan sebagai hutan kota tipe kawasan permukimana pada tiap kecamatan yang ada di Kabupaten Sidoarjo. Solusi dari penelitian ini adalah dengan menggunakan parameter yang berdasar pada Peraturan Pemerintah Republik Indonesia tentang Hutan Kota, yaitu jumlah penduduk, banyak perusahaan, ketinggian wilayah, dan luas lahan standar.

2. Membuat struktur hierarcy yang terdiri dari tujuan/goal, kriteria, dan alternatif.

Tujuan/goal, kriteria, dan altenatif pada penelitian ini dapat dilihat pada Gambar 4.

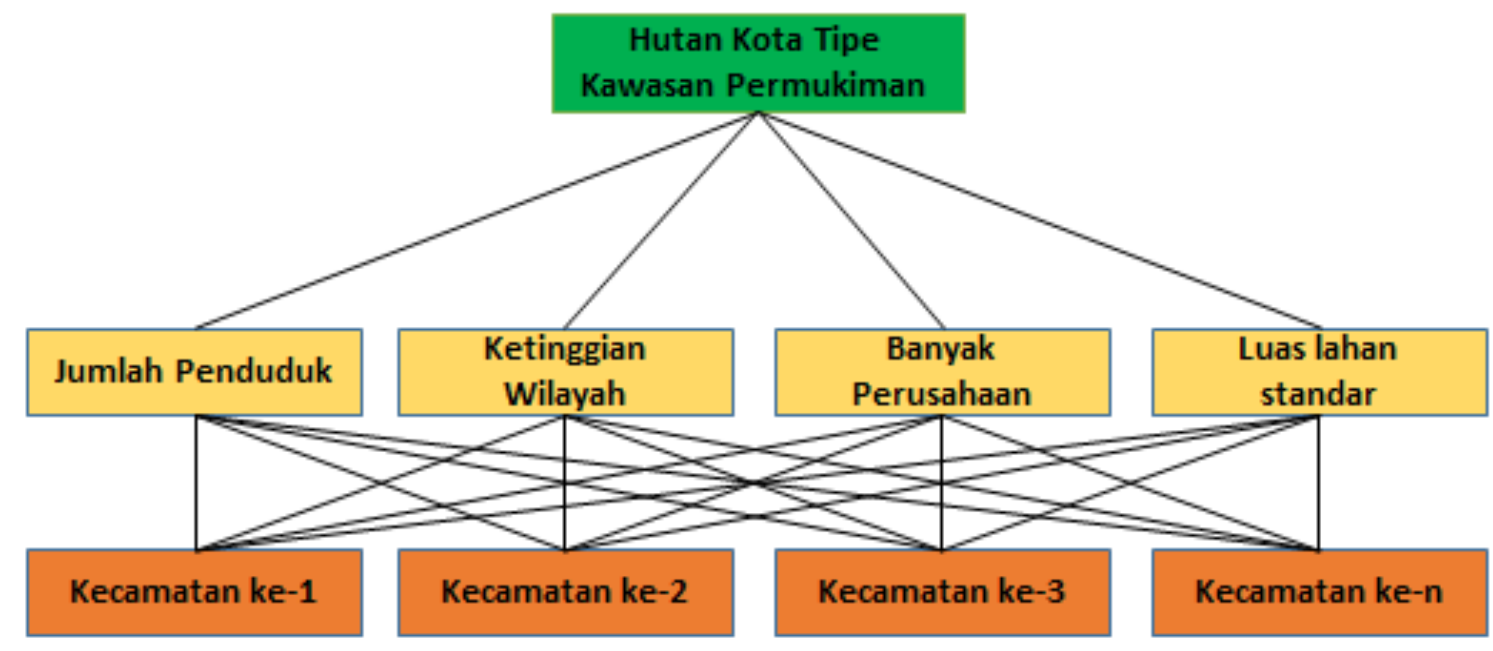

Gambar 4. Struktur AHP Pengembangan Hutan Kota 
3. Menentukan nilai kepentingan kriteria dan alternatif masing-masing kriteria hutan kota.

Penentuan nilai kepentingan tiap kriteria dan alternatif masing-masing kriteria dalam penelitian ini dilakukan oleh seorang pakar atau dalam hal ini Pihak DLHK Kabupaten Sidoarjo
Bidang Pertamanan. Dimana, dalam penentuan nilai kepentingan kriteria harus mengacu pada rangking kriteria hutan kota pada Tabel 7 dan rangking alternatif masingmasing kriteria pada Tabel 8, agar lebih mempermudah dalam menentukan nilai kepentingan kriteria.

Table 7. Rangking Kriteria Hutan Kota

\begin{tabular}{lcl}
\hline Kriteria (Parameter) & Rangking & Keterangan \\
\hline Jumlah penduduk & 2 & Mendapatkan nilai prioritas terbesar kedua \\
\hline Ketinggian wilayah & 4 & Mendapatkan nilai prioritas terbesar keempat \\
\hline Banyak perusahaan & 1 & Mendapatkan nilai prioritas terbesar pertama \\
\hline Luas lahan standar & 3 & Mendapatkan nilai prioritas tersebesar ketiga \\
\hline
\end{tabular}

Table 8. Rangking Alternatif Pada Masing-masing Kriteria

\begin{tabular}{llclll}
\hline Alternatif & \multicolumn{1}{c}{ Kriteria } & Rangking & \multicolumn{2}{c}{ Keterangan } \\
\hline Kecamatan \\
Buduran & Jumlah Penduduk & 2 & \multicolumn{2}{l}{ Mendapatkan nilai prioritas terbesar kedua } \\
\cline { 2 - 6 } & Banyak Perusahaan & 2 & \multicolumn{2}{l}{ Mendapatkan nilai prioritas terbesar kedua } \\
\cline { 2 - 6 } & Ketinggian Wilayah & 3 & $\begin{array}{l}\text { Mendapatkan } \\
\text { ketiga }\end{array}$ & nilai prioritas tersebesar \\
& Luas Lahan Standar & 1 & $\begin{array}{l}\text { Mendapatkan } \\
\text { pertama }\end{array}$ & nilai prioritas & terbesar \\
\hline
\end{tabular}

4. Membuat matriks perbandingan berpasangan.

Pembuatan matriks perbandingan berpasangan kriteria mengacu pada Tabel 7 dan matriks perbandingan alternatif kriteria mengacu pada Tabel 8, dimana dalam penentuan nilai kepentingannya akan berdasarkan Tabel 2 . Tabel matriks perbandingan berpasangan kriteria dapat dilihat pada Tabel 9 dan matriks perbandingan alternatif kriteria dapat dilihat pada Tabel 10.

Table 9. Matriks Perbandingan Berpasangan Kriteria

\begin{tabular}{ccccc}
\hline & BP & JP & LLS & KW \\
\hline BP & 1 & $3 / 1$ & $5 / 1$ & $7 / 1$ \\
\hline JP & $1 / 3$ & 1 & $3 / 1$ & $5 / 1$ \\
\hline LLS & $1 / 5$ & $1 / 3$ & 1 & $3 / 1$ \\
\hline KW & $1 / 7$ & $1 / 5$ & $1 / 3$ & 1 \\
\hline
\end{tabular}

Table 10. Matriks Perbandingan Berpasangan Alternatif Kriteria

\begin{tabular}{ccccc} 
& LLS & BP & JP & KW \\
\hline LLS & 1 & $3 / 1$ & $3 / 1$ & $5 / 1$ \\
\hline BP & $1 / 3$ & 1 & 1 & $3 / 1$ \\
\hline JP & $1 / 3$ & 1 & 1 & $3 / 1$ \\
\hline KW & $1 / 5$ & $1 / 3$ & $1 / 3$ & 1 \\
\hline
\end{tabular}

dimana BP adalah Banyak Perusahaan, JP adalah Jumlah Penduduk, LSS adalah Luas Lahan Standar dan KW adalah Ketinggian Wilayah.

5. Menghitung bobot prioritas.

Perhitungan bobot priortias kriteria dan alternatif kriteria pada penelitian ini memiliki tahapan-tahapan sebagai berikut:

a) Menghitung matriks perbandingan berpasangan.

dimana setelah penentuan nilai kepentingan kriteria dan alternatif kriteria selesai, dilakukan perhitungan matriks perbandingan 
yang hasil perhitungannya dapat dilihat pada Tabel 11 dan Tabel 12.

Table 11. Perhitungan Matriks Kriteria

\begin{tabular}{ccccc}
\hline & BP & JP & LLS & KW \\
\hline BP & 1.00 & 3.00 & 5.00 & 7.00 \\
\hline JP & 0.33 & 1.00 & 3.00 & 5.00 \\
\hline LLS & 0.20 & 0.33 & 1.00 & 3.00 \\
\hline KW & 0.14 & 0.20 & 0.33 & 1.00 \\
\hline
\end{tabular}

Table 12. Perhitungan Matriks Alternatif Kriteria

\begin{tabular}{ccccc}
\hline & LLS & BP & JP & KW \\
\hline LLS & 1.00 & 3.00 & 3.00 & 5.00 \\
\hline BP & 0.33 & 1.00 & 1.00 & 3.00 \\
\hline JP & 0.33 & 1.00 & 1.00 & 3.00 \\
\hline KW & 0.20 & 0.33 & 0.33 & 1.00
\end{tabular}

b) Jumlahkan nilai pada satu kolom dan lakukan pada setiap kolom menggunakan Persamaan (1).

Hasil jumlah tiap kolom dapat dilihat pada Tabel 13 dan Tabel 14.

Table 13. Penjumlahan Tiap Kolom Matriks Kriteria

\begin{tabular}{ccccc}
\hline & BP & JP & LLS & KW \\
\hline BP & 1.00 & 3.00 & 5.00 & 7.00 \\
\hline JP & 0.33 & 1.00 & 3.00 & 5.00 \\
\hline LLS & 0.20 & 0.33 & 1.00 & 3.00 \\
\hline KW & 0.14 & 0.20 & 0.33 & 1.00 \\
\hline Jumlah & $\mathbf{1 . 6 8}$ & $\mathbf{4 . 5 3}$ & $\mathbf{9 . 3 3}$ & $\mathbf{1 6 . 0 0}$ \\
\hline
\end{tabular}

Table 14. Penjumlahan Tiap Kolom Matriks Alternatif Kriteria

\begin{tabular}{ccccc}
\hline & LLS & BP & JP & KW \\
\hline LLS & 1.00 & 3.00 & 3.00 & 5.00 \\
\hline BP & 0.33 & 1.00 & 1.00 & 3.00 \\
\hline JP & 0.33 & 1.00 & 1.00 & 3.00 \\
\hline KW & 0.20 & 0.33 & 0.33 & 1.00 \\
\hline Jumlah & $\mathbf{1 . 8 7}$ & $\mathbf{5 . 3 3}$ & $\mathbf{5 . 3 3}$ & $\mathbf{1 2 . 0 0}$ \\
\hline
\end{tabular}

c) Membagi nilai setiap kolom dengan hasil jumlah nilai masing-masing kolom pada Tabel 13 dan Tabel 14, sehingga nilai jumlah kolom yang baru sama dengan satu menggunakan Persamaan (2).

Hasil pembagian nilai tiap kolom dengan jumlah tiap kolom dapat dilihat pada Tabel 15 dan Tabel 16.

Table 15. Pembagian Tiap Kolom Matriks

\begin{tabular}{ccccc}
\multicolumn{5}{c}{ Kriteria } \\
\hline & BP & JP & LLS & KW \\
\hline BP & 0.60 & 0.66 & 0.54 & 0.44 \\
\hline JP & 0.20 & 0.22 & 0.32 & 0.31 \\
\hline LLS & 0.12 & 0.07 & 0.11 & 0.19 \\
\hline KW & 0.08 & 0.04 & 0.04 & 0.06 \\
\hline Jumlah & 1 & 1 & 1 & 1 \\
\hline
\end{tabular}

Table 16. Pembagian Tiap Kolom Matriks Alternatif Kriteria

\begin{tabular}{ccccc}
\hline & LLS & BP & JP & KW \\
\hline LLS & 0.54 & 0.56 & 0.56 & 0.42 \\
\hline BP & 0.18 & 0.19 & 0.19 & 0.25 \\
\hline JP & 0.18 & 0.19 & 0.19 & 0.25 \\
\hline KW & 0.11 & 0.06 & 0.06 & 0.08 \\
\hline Jumlah & 1 & 1 & 1 & 1 \\
\hline
\end{tabular}

d) Menjumlahkan nilai tiap baris dari hasil pembagian tiap kolom matriks (Tabel 15 dan Tabel 16) menggunakan Persamaan (3).

Hasil jumlah nilai tiap baris dapat dilihat pada Tabel 17 dan Tabel 18.

Table 17. Jumlah Tiap Baris Matriks Kriteria

\begin{tabular}{cc}
\hline Kriteria & Jumlah Baris \\
\hline Banyak perusahaan & 2.23 \\
\hline Jumlah penduduk & 1.05 \\
\hline Luas lahan standar & 0.49 \\
\hline Ketinggia wilayah & 0.23 \\
\hline
\end{tabular}

Table 18. Jumlah Tiap Baris Matriks Alternatif Kriteria

\begin{tabular}{cc}
\hline Kriteria & Jumlah Baris \\
\hline Luas lahan standar & 2.08 \\
\hline Banyak perusahaan & 0.80 \\
\hline Jumlah penduduk & 0.80 \\
\hline Ketinggia wilayah & 0.32 \\
\hline
\end{tabular}

e) Membagi hasil jumlah tiap baris (Tabel 17 dan Tabel 18) dengan banyaknya kriteria untuk mendapatkan bobot prioritas kriteria dan bobot prioritas alternatif kriteria menggunakan Persamaan (4).

Hasil perhitungan bobot prioritas dapat dilihat 
pada Tabel 19 dan Tabel 20.

Table 19. Bobot Prioritas Kriteria

\begin{tabular}{cc}
\hline Kriteria & Bobot Prioritas \\
\hline Banyak perusahaan & 0.56 \\
\hline Jumlah penduduk & 0.26 \\
\hline Luas lahan standar & 0.12 \\
\hline Ketinggia wilayah & 0.06 \\
\hline
\end{tabular}

Table 20. Bobot Prioritas Alternatif Kriteria Kriteria Bobot Prioritas

\begin{tabular}{cc}
\hline Luas lahan standar & 0.56 \\
\hline Banyak perusahaan & 0.26 \\
\hline Jumlah penduduk & 0.12 \\
\hline Ketinggia wilayah & 0.06 \\
\hline
\end{tabular}

6. Menghitung nilai $\mathrm{CW}$ kriteria dan alternatif kriteria menggunakan persamaan (5).

Hasil CW kriteria dan alternatif kriteria dapat dilihat pada Tabel 21 dan 22.

Table 21. Nilai Composite Weight Kriteria

\begin{tabular}{cccccc}
\hline & BP & JP & LLS & KW & Total \\
\hline BP & 0.56 & 0.79 & 0.61 & 0.40 & 2.35 \\
\hline JP & 0.18 & 0.26 & 0.37 & 0.28 & 1.10 \\
\hline LLS & 0.11 & 0.09 & 0.12 & 0.17 & 0.49 \\
\hline KW & 0.08 & 0.05 & 0.04 & 0.06 & 0.23 \\
\hline
\end{tabular}

Table 22. Nilai Composite Weight Alternatif Kriteria

\begin{tabular}{cccccc}
\hline & LLS & BP & JP & KW & Total \\
\hline LLS & 0.52 & 0.60 & 0.60 & 0.39 & 2.12 \\
\hline BP & 0.17 & 0.20 & 0.20 & 0.24 & 0.81 \\
\hline JP & 0.17 & 0.20 & 0.20 & 0.24 & 0.81 \\
\hline KW & 0.10 & 0.07 & 0.07 & 0.08 & 0.32 \\
\hline
\end{tabular}

7. Melakukan uji konsistensi.

Tahapan uji konsistensi pada penelitian ini adalah sebagai berikut :

a) Menghitung nilai lamda kriteria dan alternatif kriteria menggunakan Persamaan (6).

Hasil perhitungan nilai lamda dapat dilihat pada Tabel 23 dan Tabel 24.
Table 23. Nilai Lamda Kriteria

\begin{tabular}{cc}
\hline Kriteria & Nilai Lamda $\left(\boldsymbol{\lambda}_{\boldsymbol{i}}\right)$ \\
\hline Banyak perusahaan & 4.21 \\
\hline Jumlah penduduk & 4.16 \\
\hline Luas lahan standar & 4.02 \\
\hline Ketinggia wilayah & 4.03 \\
\hline
\end{tabular}

Table 24. Nilai Lamda Alternatif Kriteria

\begin{tabular}{cc}
\hline Kriteria & Nilai Lamda $\left(\boldsymbol{\lambda}_{\boldsymbol{i}}\right)$ \\
\hline Luas lahan standar & 4.08 \\
\hline Banyak perusahaan & 4.04 \\
\hline Jumlah penduduk & 4.04 \\
\hline Ketinggia wilayah & 4.02 \\
\hline
\end{tabular}

b) Menghitung nilai lamda maksimal dengan menggunakan Persamaan (7) sehingga didapati nilai lamda maksimal kriteria adalah $\lambda_{\text {maks }}=4.11$ dan lamda maksimal alternatif kriteria adalah $\lambda_{\text {maks }}=4.04$

c) Menghitung nilai CI menggunakan Persamaan (8), sehingga didapati nilai CI kriteria adalah $C I=0.03$, dan nilai $\mathrm{CI}$ alternatif kriteria adalah $C I=0.01$

d) Menghitung nilai CR menggunakan Persamaan (9), sehingga didapati nilai CR kriteria adalah $C R=0.04$, dan nilai $C R$ alternatif kriteria adalah $C R=0.02$

Hasil perhitungan kriteria dan alternatif kriteria didapati nilai $\mathrm{CR} \leq 0,1$. Maka hasil perhitungan kriteria dan alternatif kriteria dinyatakan konsisten. Proses perhitungan kemudian dilanjutkan dengan menghitung nilai perkalian bobot prioritas alternatif kriteria dengan bobot prioritas kriteria sebagai berikut :

- hasilakhir $=(($ bobot prioritas alternatif kriteria banyak perusahaan $\times$ bobot prioritas kriteria banyak perusahaan) + (bobot prioritas alternatif kriteria jumlah penduduk $\times$ bobot prioritas kriteria jumlah penduduk) + (bobot prioritas alternatif kriteria luas lahan standar $\times$ bobot prioritas kriteria luas lahan standar) + (bobot prioritas alternatif kriteria ketinggian wilayah $\times$ bobot prioritas kriteria ketinggian wilayah)) 
- hasilakhir $=((0.20 \times 0.58)+(0.20 \times 0.27)$ $+(0.52 \times 0.10)+(0.08 \times 0.05))$

- hasilakhir $=0.12+0.05+0.05+0.00$

- hasilakhir $=0.22$

Hasil perhitungan menggunakan metode AHP pada hutan kota tipe kawasan permukiman didapati nilai tertinggi pada Kecamatan Sidoarjo dengan hasilakhir $=0.84$, untuk nilai terendah pada Kecamatan Krian dengan hasilakhir $=0.21$.

Pada metode WSM dihitung dengan tahapan sebagai berikut :

1. Mengidentifikasi bobot parameter dan atribut parameter yang digunakan dalam penyelesaian masalah. Menentukan nilai/bobot parameter dan atribut masingmasing parameter yang dilakukan oleh seorang pakar. Dimana dalam hal ini Pihak DLHK Kabupaten Sidoarjo Bidang Pertamanan. Bobot parameter dan bobot atribut parameter dapat dilihat pada Tabel 26 dan Tabel 27. Pemberian bobot parameter dan atribut parameter suatu kecamatan akan mengacu atau menyesuaikan pada data lapangan atau data atribut dari Kecamatan Sidoarjo (Tabel 25).

Table 25. Data Atribut Kecamatan Sidoarjo

\begin{tabular}{ccccc}
\hline Kecamatan & $\begin{array}{c}\text { Banyak } \\
\text { Perusahaan }\end{array}$ & $\begin{array}{c}\text { Jumlah } \\
\text { Penduduk (jiwa) }\end{array}$ & $\begin{array}{c}\text { Ketinggian } \\
\text { Wilayah (meter) }\end{array}$ & $\begin{array}{c}\text { Luas lahan standar } \\
\text { (hektar) }\end{array}$ \\
\hline Sidoarjo & 13 & 228276 & 4 & 9.05 \\
\hline
\end{tabular}

Table 26. Bobot Parameter Hutan Kota

\begin{tabular}{cc}
\hline Parameter & Nilai Bobot \\
\hline Jumlah Penduduk & 3 \\
\hline Ketinggian Wilayah & 1 \\
\hline Banyak Perusahaan & 2 \\
\hline Luas Lahan Standar & 4 \\
\hline
\end{tabular}

Table 27. Bobot Atribut Parameter Hutan Kota

\begin{tabular}{|c|c|c|c|c|c|}
\hline Hutan Kota & Parameter & Range & Satuan & Keterangan & Bobot \\
\hline \multirow{12}{*}{$\begin{array}{l}\text { Tipe kawasan } \\
\text { permukiman }\end{array}$} & \multirow[t]{4}{*}{ Jumlah penduduk } & $\leq 50$ & Jiwa & Tidak padat & 5 \\
\hline & & $51-250$ & Jiwa & Kurang padat & 6 \\
\hline & & $251-400$ & Jiwa & Cukup padat & 7 \\
\hline & & $\geq 400$ & Jiwa & Sangat padat & 8 \\
\hline & \multirow[t]{3}{*}{ Banyak perusahaan } & $1-2$ & Unit & Rendah & 2 \\
\hline & & $3-7$ & Unit & Sedang & 6 \\
\hline & & $8-11$ & Unit & Tinggi & 9 \\
\hline & \multirow[t]{3}{*}{ Ketinggian wilayah } & $0-3$ & Meter & Rendah & 2 \\
\hline & & $4-10$ & Meter & Sedang & 6 \\
\hline & & $11-25$ & Meter & Tinggi & 8 \\
\hline & \multirow[t]{2}{*}{ Luas lahan standar } & $\leq 25$ & Hektar & Tidak cocok & 1 \\
\hline & & $\geq 25$ & Hektar & Cocok & 8 \\
\hline
\end{tabular}

2. Menghitung nilai WSM-Score menggunakan Persamaan (10).
$A_{i}=$ (bobot parameter jumlah penduduk $\times$ bobot atribut parameter jumlah penduduk 
kecamatan sidoarjo) + (bobot parameter ketinggian wilayah $\times$ bobot atribut parameter ketinggian wilayah kecamatan sidoarjo) + (bobot parameter banyak perusahaan $\times$ bobot atribut parameter banyak perusahaan kecamatan sidoarjo) + (bobot parameter luas lahan standar $\times$ bobot atribut parameter luas lahan standar kecamatan sidoarjo).

$A_{1}=((4 \times 9)+(3 \times 8)+(2 \times 1)+(1 \times 6))=68$

3. Melakukan perangkingan nilai alternatif $A_{i}$. Proses perangkingan pada metode WSM dilakukan dengan mengurutkan nilai yang paling terbesar sampai dengan nilai yang terkecil. Dimana nilai paling besar menempati rangkin pertama, diikuti dengan nilai rangking berikutnya.

Hasil perhitungan menggunakan metode WSM pada hutan kota tipe kawasan permukiman didapati nilai tertinggi pada Kecamatan Krian dengan nilai $A_{i}=70$, untuk nilai terendah pada Kecamatan Prambon dengan nilai $A_{i}=40$.

\section{KESIMPULAN}

Hasil perhitungan menggunakan metode AHP pada hutan kota tipe kawasan permukiman didapati 0 kecamatan tidak cocok, 17 kecamatan cocok, dan 1 kecamatan sangat cocok. Hasil perhitungan menggunakan metode WSM pada hutan kota tipe kawasan permukiman didapati 0 kecamatan tidak cocok, 7 kecamatan cocok, dan 11 kecamatan sangat cocok.

Hasil uji validasi metode AHP dan metode WSM dengan menggunakan Cohen's Kappa pada hutan kota tipe kawasan permukiman memiliki kekuatan kesepakatan "rendah" dengan nilai $\mathrm{K}=0.07$.

Pengembangan penelitian lebih lanjut yaitu perlu adanya penambahan beberapa parameter lain seperti luas wilayah dan pencemaran udara dan juga perlu adanya uji coba penelitian dengan menggunakan metode lainnya yang mendukung dengan penggunaan parameter.

\section{DAFTAR PUSTAKA}

[1] Peraturan Pemerintah Republik Indonesia Tentang Hutan Kota. 2002.

[2] Peraturan Menteri Kehutanan Republik Indonesia Nomor : P.71/Menhut-II/2009 Tentang Pedoman Penyelenggaraan Hutan Kota. 2009.

[3] Peraturan Menteri Pekerjaan Umum Tentang Pedoman Penyediaan dan Pemanfaatan Ruang Terbuka Hijau di Kawasan Perkotaan. 2008.

[4] M. B. Sri Sapti, Chafid Fandeli, "Studi Kebutuhan Hutan Kota Berdasarkan Kemampuan Vegetasi Dalam Penyerapan Karbon di Kota Mataram," Geogr. UGM, vol. 24, no. 1, pp. 1-9, 2010.

[5] B. P. S. P. J. Ti and Mur, Provinsi Jawa Timur Dalam Angka 2020. BPS Provinsi Jawa Timur, 2020.

[6] R. N. Sari, "Ketersediaan Ruang Terbuka Hijau Berbasis Pelestarian Lingkungan di Kabupaten Sidoarjo,” J. Polit. dan Sos. Kemasyarakatan, vol. 53, no. 9, pp. 1689-1699, 2018.

[7] S. Narulita, A. F. M. Zain, and L. B. Prasetyo, "Geographic Information System (GIS) Application on Urban Forest Development in Bandung City," Procedia Environ. Sci., vol. 33, pp. 279289, 2016.

[8] L. B. P. G. A. Rachmad Hermawan, "Use of Geographical Information System (GIS) and remote sensing in development of urban forest types and shapes in Tangerang Selatan City," Earth Environ. Sci., vol. 755, 2017.

[9] Y. Zheng et al., "Visual sensitivity versus ecological sensitivity: An application of GIS in urban forest park 
planning," Urban For. Urban Green., vol. 41, pp. 139-149, 2019.

[10] R. Salambue, . N., R. Putra Pratama, and

B. Putra, "Sistem Informasi Geografis Menggunakan Multi Criteria Evaluation Untuk Zonasi Wisata Bahari Pantai Rupat," J. Nas. Teknol. dan Sist. Inf., vol. 2, no. 3, pp. 167-174, 2016.

[11] S. A.V. Vitianingsih, A. Choiron, D. Cahyono, A. Umam, "Spatial Data Modeling on GIS for Classification of Measles-prone Region Using Multiple Attribute Decision Making," Econ. Bussiness Fac., 2018.

[12] L. M. Yulyantari, Manajemen Model Pada Sistem Pendukung Keputusan. Yogyakarta: Andi, 2019.

[13] M. K. Dicky Nofriansyah, S.Kom. and M. S. Prof. Dr. Sarjon Defit, S.Kom., Multi Criteria Decision Making (MCDM) pada Sistem Pendukung Keputusan. Yogyakarta: CV BUDI UTAMA, 2019.

[14] L. Guttman, A Basic for Scalling Qualitative Data, Vol. 9, No. Am. Sociol. Rev, 1944.

[15] M. S. Ahmat Adil, S.kom., Sistem Informasi Geografis. Yogyakarta, 2017.

[16] R. Azen and C. M. Walker, Categorical Data Analysis for the Behavioral and Social Sciences. Taylor \& Francis Group, 2011. 